Volume 2 Nomor 2, Desember 2019

E-ISSN : 2655-7347

\title{
KEWENANGAN BADAN PENYELESAIAN SENGKETA KONSUMEN DALAM MENANGANI SENGKETA ANTARA PT. SINAR MENARA DELI DENGAN SARI ALAMSYAH
}

\author{
Samuel \\ (Mahasiswa Program S1 Fakultas Hukum Universitas Tarumanagara) \\ (E-mail: fillipusam94@gmail.com)
}

Dr. Dra. Siti Nurbaiti, S.H., M.H.

(Corresponding Author)

(Dosen Fakultas Hukum Universitas Tarumanagara. Meraih Sarjana Hukum pada Fakultas Hukum Universitas Trisakti, Magister Hukum pada Fakultas Hukum Universitas Tarumanagara, Doktor

(Dr.) pada Fakultas Hukum Universitas. Trisakti)

(E-mail: Nurbaiti_05092000@yahoo.com)

\begin{abstract}
In principle, the resolution of consumer disputes can be pursued peacefully. through an alternative mediation dispute resolution. In Law Number 8 of 1999 concerning Consumer Protection and Regulation of the Minister of Trade of the Republic of Indonesia Number 6 / MDAG / PER / 2017 concerning the Consumer Dispute Settlement Body does not impose limits on the authority of BPSK in handling and adjudicating a consumer dispute. However, in reality many times the decisions of the Consumer Dispute Settlement Body (BPSK) are submitted to the district court and stated that BPSK is not authorized to handle such disputes. How is the authority of the Consumer Dispute Resolution Board in handling disputes between PT. Sinar Menara Deli and Sari Alamsyah are the issues discussed. The method used in this research is descriptive normative legal research, using secondary data and primary data as supporting data with the law approach. The results of the study illustrate that BPSK is not authorized to handle disputes between PT. Sinar Menara Deli with Sari Alamsyah, because the business actors in this dispute have submitted a refusal to be resolved through BPSK and not achieving the requirements for consumer disputes. It is recommended that BPSK members pay more attention to the provisions in the Consumer Protection Act and other regulations concerning the Consumer Dispute Settlement Body.
\end{abstract}

Keywords: consumer protection, Consumer Dispute Settlement Body (BPSK)

\section{PENDAHULUAN}

\section{A. Latar Belakang}

Dalam hidup bermasyarakat setiap individu-individu memiliki kepentingannya masing-masing, untuk melindungi kepentingan tersebut para individu membuat perjanjian. Dalam Bahasa belanda, perjanjian disebut overeenkomst dan hukum perjanjian adalah overeenkomstenrecht. ${ }^{1)}$ Dalam Kitab Undang-Undang Hukum Perdata Pasal 1313 meberikan definisi perjanjian atau dapat disebut juga dengan persetujuan, "Suatu persetujuan

$1 \quad$ ' C.S.T. Kansil dan Chistine S.T. Kansil, Modul Hukum Perdata Termasuk Asas-Asas Hukum Perdata, (Jakarta: Pradnya Paramita, 2000), Hal. 204. 
Volume 2 Nomor 2, Desember 2019

E-ISSN : 2655-7347

adalah perbuatan dimana seorang atau lebih mengikatkan diri kepada seorang lain atau lebih.” Peristiwa itu menimbulkan hubungan hukum diantara kedua orang tersebut disebut dengan perikatan.

Menurut Soediman Kartohadiprodjo, Hukum perikatan ialah keseluruhan kaidah yang mengatur hak dan kewajiban seorang yang bersumber pada tindakannya dalam lingkungan hukum kekayaan. ${ }^{2)}$

Menurut Subekti perikatan adalah suatu hubungan hukum antara dua orang, dimana pihak yang satu berhak menuntut sesuatu dari pihak satu, dan pihak yang lain berkewajiban untuk memenuhi tuntutan itu. ${ }^{3)}$ Seorang yang berhak menuntut sesuatu itu disebut kreditur, sedangkan pihak yang berkewajiban memenuhi tuntutan dinamakan debitur.

Dalam hukum, yang mengatur kepentingan antara individu seperti perjanjian, perwarisan, harta benda, kegiatan usaha, perkawinan termasuk dalam hukum privat atau Hukum Perdata . Menurut Subekti, Hukum Perdata dalam arti yang luas meliputi semua hukum privat materil, yaitu segala hukum pokok yang mengatur kepentingan-kepentingan perseorangan. ${ }^{4)}$ Dalam hal usaha, antara pelaku usaha dan konsumen juga membuat sebuah perjanjian dimana syarat sahnya suatu perjanjian terdapat dalam Kitab Undang-Undang Hukum Perdata pada pasal 1320.

Dalam suatu perjanjian kita mengenal prestasi dan wanprestasi, yang dimaksud dengan prestasi adalah objek perikatan. ${ }^{5)}$ Sedangkan yang dimaksud dengan wanprestasi artinya tidak memenuhi prestasi yang sudah diperjanjikan yang telah ditetapkan dalam perikatan. ${ }^{6}$ Dalam suatu perjanjian dapat terjadi suatu wanprestasi dari wanprestasi tersebut dapat menimbulkan sengketa konsumen dimana yang dimaksud dengan sengketa konsumen adalah sengketa yang berkaitan dengan pelanggaran hak-hak konsumen.

\footnotetext{
) Soediman Kartohadiprodjo, Pengantar Tata Hukum di Indonesia, (Jakarta: Ghalia Indonesia, Cet. X. 1984), Hal. 97.

$3 \quad$ ' Subekti, Hukum Perjanjian, (Jakarta: Intermasa, Cet. XV, 1994), Hal 1.

4 ) Subekti, Pokok-pokok Hukum Perdata, (Jakarta: Intermasa, 1985), hal. 9.

$5 \quad$ ) Abdulkadir Muhammad, Hukum Perdata Indonesia. (Bandung: Citra Aditya Bakti, 1990), Hal. 201.

$6 \quad$ Ibid, Hal. 203.
} 
Volume 2 Nomor 2, Desember 2019

E-ISSN : 2655-7347

Undang-Undang Nomor 8 Tahun 1999 tentang Perlindungan Konsumen diharapkan dapat melindungi kepentingan konsumen maupun kepentingan pelaku usaha. Undang-undang perlindungan konsumen ini memang sengaja dibentuk dengan beberapa pertimbangan antara lain karena dalam kenyataannya sering kali pelaku usaha mempunyai posisi lebih tinggi dibanding dengan konsumen.

Pada prinsipnya penyelesaian sengketa konsumen diusahakan dapat dilakukan secara damai, sehingga dapat memuaskan kedua belah pihak yang bersengketa. ${ }^{7)}$ Apabila tidak terjadi demikian maka upaya hukum yang dapat dilakukan oleh para pihak ada 2 yaitu melalui jalur litigasi (melalui pengadilan) dan non-litigasi (di luar pengadilan). Dalam jalur non-litigasi atau di luar pengadilan, kita mengenal Badan Penyelesaian Sengketa Konsumen (BPSK). Namun penyelesaian sengketa di luar pengadilan tersebut bukan suatu yang harus dilakukan atau dijalan terlebih dahulu. ${ }^{8)}$

Dalam Undang-Undang Nomor 8 Tahun 1999 tentang Perlindungan Konsumen dan Peraturan Menteri Perdagangan Republik Indonesia Nomor 6/ M-DAG/PER/2017 tentang Badan Penyelesaian Sengketa Konsumen tidak memberi batasan wewenang kepada BPSK dalam menangani dan mengadili suatu sengketa konsumen.

Badan Penyelesaian Sengketa Konsumen (BPSK) dibentuk untuk penyelesaian perkara yang berskala kecil karena untuk perkara-perkara kecil dianggap tidak efektif apabila diajukan dalam pengadilan yang membutuhkan waktu lebih lama dibandingkan melalui BPSK. Berdasarkan Pasal 60 Ayat (2) Undang-Undang No.8 Tahun 1999 tentang Perlindungan Konsumen yang berbunyi: “Sanksi administratif berupa penetapan ganti rugi paling banyak Rp. 200.000.000,00 (dua ratus juta rupiah).” Berdasarkan Pasal 54 Ayat (3) Undang-Undang Perlindungan Konsumen yang berbunyi: "Putusan majelis final dan mengikat.” Dalam hal ini dapat diartikan bahwa keputusan yang

\footnotetext{
7) C.S.T. Kansil dan Chistine S.T. Kansil, Op.Cit., Hal. 291.

) Mia hadiati. Mariske Myeke Tampi. "Efektivitas mediasi dalam penyelesaian sengketa konsumen oleh badan penyelesaian sengketa konsumen (BPSK) di D.K.I Jakarta”. Jurnal Hukum Prioris. Vol. 6. No. 1 Tahun 2017. Hal. 70.
} 
Volume 2 Nomor 2, Desember 2019

E-ISSN : 2655-7347

dikeluarkan oleh BPSK adalah final tidak dapat melakukan banding atau keberatan.

Namun pada kenyataannya sering kali putusan Badan Penyelesaian Sengketa Konsumen (BPSK) diajukan keberatan ke pengadilan negeri dan dinyatakan bahwa BPSK tidak berwenang untuk menangani sengketa tersebut. Seperti salah satu contoh pada putusan BPSK Medan No.049/PEN/2018/BPSK.MDN yang kemudian diajukan keberatan ke Pengadilan Negeri Medan dan dinyatakan BPSK kota Medan tidak berwenang.

Berdasarkan hal-hal tersebut, Penulis tertarik untuk melakukan penelitian lebih lanjut yang kemudian dituangkan dalam skripsi yang berjudul “Kewenangan BPSK dalam mengadili sengketa antara PT. Sinar Menara Deli selaku pelaku usaha dengan Sari Alamsyah selaku konsumen.”

\section{B. Perumusan Masalah}

Berdasarkan uraian dalam latar belakang, maka dapat disampaikan rumusan permasalahan sebagai berikut: Bagaimana kewenangan Badan Penyelesaian Sengketa Konsumen dalam menangani sengketa antara PT. Sinar Menara Deli selaku pelaku usaha dengan Sari Alamsyah selaku konsumen?

\section{Metode Penelitian}

Metode yang digunakan dalam penelitian ini adalah penelitian hukum normatif. Penelitian hukum normatif adalah penelitian hukum yang dilakukan dengan cara meneliti bahan-bahan pustaka. ${ }^{9)}$ Dalam menjawab permasalahan hukum yang diangkat oleh penulis, penulis menggunakan pendekatan undangundang, pendekatan kasus dan pendekatan konseptual. Dalam pendekatan undang-undang penulis akan menerapkan peraturan perundang-undangan yang ada dan menganalisis wewenang Badan Penyelesaian Sengketa Konsumen dengan cara arbitrase. Dalam pendekatan kasus penulis akan menjabarkan kasus yang diteliti serta mengimplementasikan hukum yang berlaku kepada kasus tersebut. Pendekatan terakhir adalah pendekatan konseptual, penulis akan berpijak pada berbagai teori-teori dan doktrin-doktrin.

\footnotetext{
$9 \quad$ ' Soerjono Soekanto dan Sri Mamudji, Penelitian Hukum Normatif: Suatu Tinjauan Singkat, (Jakarta: RajaGrafindo Persada, 2006), Hal. 13.
} 
Volume 2 Nomor 2, Desember 2019

E-ISSN : 2655-7347

\section{PEMBAHASAN}

\section{A. URAIAN DAN PENJELASAN KASUS}

Pada tanggal 22 April 2014 dilakukan Perjanjian Pengikatan Jual Beli satuan rumah susun di Podomoro City Deli-Medan No. 00001109 atas 1 (satu) unit rumah susun (apartemen), oleh Sari Alamsyah selaku konsumen dengan PT. Sinar Menara Deli yang dikenal dengan Podomoro City DeliMedan. Lalu pada tanggal 14 November 2014 dilakukan konfirmasi atas pemesanan 1 (satu) unit rumah susun (apartemen) dengan surat konfirmasi unit pesanan No. 002044 dan surat pemesanan Podomoro City Deli-Medan No. 0000001219.

Harga Pengikatan totalnya adalah Rp. 2.332.840.000 (dua miliar tiga ratus tiga puluh dua juta delapan ratus empat puluh rupiah) dengan cara pembayaran Secara tunai (kontan) bertahap yang jumlah angsuran (cicilan). Pada pelaksanaannya Sari Alamsyah membayar sesuai dengan perjanjian hanya sampai angsuran ke-12, pada angsuran ke-13 Sari Alamsyah hanya membayar sebesar Rp. 20.000.000,- (Dua puluh juta rupiah). Sejak Pembayaran ke-13 tersebut Sari Alamsyah tidak lagi menjalankan kewajibannya berdasarkan perjanjian yang disepakati.

PT. Sinar Menara Deli sudah memberikan surat teguran (somasi) terkait penunggakan pembayaran angsuran ke-13 yang jatuh tempo pada tanggal 19 Desember 2015 dengan surat No. 02775/FA/SP-1-MDN/XII/15 Tanggal 28 Desember 2015 tentang teguran (somasi) ke-1. Karena belum ada respon dari pihak konsumen, PT. Sinar Menara Deli ini mengirim surat kembali pada tanggal 5 januari 2016, surat No. 02790A/FA/SP2-MDN/I/16 tentang teguran (somasi) ke-2 terhadap tunggakan kewajiban pembayaran dan sanksi atas pelanggarannya dan Surat No/ 02827A/FA/SP3-MDN/I/16 pada tanggal 13 januari 2016 tentang teguran (somasi) terakhir terhadap tunggakan kewajiban pembayaran dan tindak lanjut pembatalan perjanjian (SKUP), Surat Pemesanan dan/atau PPJB). Setelah dilakukan somasi-somasi ternyata Sari Alamsyah (Konsumen) tetap tidak menyelesaikan tunggakan kewajiban pembayaran, bahkan konsumen mengajukan laporan ke BPSK. Pemesanan 
Volume 2 Nomor 2, Desember 2019

E-ISSN : 2655-7347

Unit Pesanan dan Perjanjian Pengikatan Jual Beli Satuan Rumah Susun Di Podomoro City Deli-Medan No. 00001109 tanggal 22 April 2015 telah dibatalkan pada tanggal 20 Januari 2016, sebagaimana dalam surat No. 02874A/FA/SP4-MDN/I/16 tanggal 28 Januari 2016 tentang Pemberitahuan Pembatalan Unit LEX/09/DM di Proyek Podomoro City Deli-Medan. Pada tanggal 4 November 2016, yaitu lebih dari 9 (sembilan) bulan kemudian lamanya, Sari Alamsyah menyampaikan surat kepada PT. Sinar Menara Deli yang pada pokoknya menyatakan bahwa Sari Alamsyah ada masalah keuangan dan mohon kebijakan management agar unit pesanannya tidak dibatalkan dan berencana untuk melunasi via KPA Bank BNI segera. Namun Sari Alamsyah tidak melakukan pembayaran apapun setelah mengirimkan surat tersebut.

Tanggal 2 Mei 2018, yaitu lebih dari 2 tahun 3 bulan lamanya sejak tanggal pembatalan, Sari Alamsyah mengajukan pengaduan ke Badan Penyelesaian Sengketa Konsumen (“BPSK”) Kota Medan dengan mempermasalahkan tentang adanya klausula baku dalam perjanjian yang dibuat dan disepakati Bersama. PT. Sinar Menara Deli telah menyampaikan secara resmi surat tanggal 31 Mei 2018 tentang Tanggapan atas Surat Pengaduan Sdr. Sari Alamsyah. Pada tanggal 7 Juni 2018 PT. Sinar Menara Deli yang di wakili oleh Herjanto Widjaja Lowardi, S.H., M. Kn., Miarni Ang, S.H., M.Kn., dan Tommi Jaya Arya, S.H., hadir dalam prasidang berikutnya dalam perkara No. 049/Pen/2018/BPSK.Mdn di BPSK Kota Medan. Dan dalam sidang tersebut pihak PT. Sinar Menara Deli menyampaikan secara lisan dan tertulis mengenai penolakan secara resmi dan tegas selaku Pelaku Usaha terhadap pemeriksaan, penanganan dan penyelesaian yang akan dilakukan terhadap pengaduan Sari Alamsyah selaku Konsumen di BPSK. Pada tanggal 5 Juli 2015 wakil PT. Sinar Menara Deli hadir lagi dalam prasidang perkara No. 049/Pen/2018/BPSK.Mdn di BPSK Kota Medan dan mereka menyampaikan kembali isi surat keberatan tanggal 31 Mei 2018 tersebut tentang keberatan dan menolak pengaduan Sdr. Sari Alamsyah dalam register perkara No. 049/Pen/2018/BPSK.Mdn diperiksa, 
Volume 2 Nomor 2, Desember 2019

E-ISSN : 2655-7347

ditangani dan diselesaikan di BPSK Kota Medan atau oleh Majelis BPSK Kota Medan, Namun ternyata Majelis BPSK dalam perkara No. 049 / Pen/ 2018 /BPSK. Mdn di BPSK Kota Medan memaksakan kehendak dengan menyatakan akan mengeluarkan putusan dalam sidang berikutnya minggu depan. Pada tanggal 16 Agustus 2018 pihak BPSK Kota Medan menyampaikan Surat Pemberitahuan Putusan No. 100 /VIII /2018 /BPSK .MDN kepada pihak PT. Sinar Menara Deli, karena adanya pemaksaan kehendak memeriksa dan memutuskan pengaduan tanpa persetujuan dari pihak PT. Sinar Menara Deli selaku Pelaku Usaha, maka dalam jangka waktu 14 (empat belas) hari kerja terhitung sejak tanggal pemberitahuan putusan, PT. Sinar Menara Deli mengajukan keberatan atas Putusan BPSK Medan No. 049/ Pen/ 2018 / BPSK.Mdn. Dalam melakukan laporan kepada Badan Penyelesaian Sengketa Konsumen Medan yang dipermasalahkan oleh Sari Alamsyah terkait klausula baku. Berdasarkan Surat Pemesanan Podomoro City Deli-Medan No. 0000001219 tanggal 14 November 2014 dan Perjanjian Pengikatan Jual Beli Satuan Rumah Susun Di Podomoro City Deli-Medan No. 00001109 tanggal 22 April 2015 yang dipermasalahkan oleh Sari Alamsyah selaku konsumen adalah sebagai berikut:

1. Mengenai Pembatalan Butir 6 Surat Pemesanan Podomoro City DeliMedan No. 0000001219 tanggal 14 November 2014 berbunyi sebagai berikut:

“Apabila terjadi keterlambatan pembayaran selama 30 (tiga puluh) hari kalender terhitung sejak tanggal jatuh tempo kewajiban pembayaran yang bersangkutan, maka Penerima Pesanan berhak membatalkan secara sepihak pemesanan atas Unit Pesanan, dengan melepaskan ketentuan dalam Pasal 1266 dan Pasal 1267 Kitab Undang-Undang Hukum Perdata, dan Penerima Pesanan hanya akan mengembalikan 50\% (lima puluh persen) dari jumlah uang yang telah dibayarkan oleh Pemesan kepada Penerima Pesanan setelah dikurangi uang tanda jadi (Booking Fee), Pajak Pertambahan Nilai (PPN), Pajak Penghasilan (PPh) Penerima Pesanan, biaya administrasi pembatalan dan kewajiban pembayaran lainnya (bila ada).”

2. Pasal 4 Ayat (2), Pasal 4 Ayat (4), dan Pasal 14 Ayat (1) dan (2)

Perjanjian Pengikatan Jual Beli Satuan Rumah Susun Di Podomoro 
Volume 2 Nomor 2, Desember 2019

E-ISSN : 2655-7347

City Deli-Medan No. 00001109 tanggal 22 April 2015 berbunyi sebagai berikut:

a) Pasal 4 Ayat (2):

"Jika Pihak Kedua lalai atau tidak membayar angsuran dan/atau kewajiban pembayaran lainnya berdasarkan Perjanjian ini pada waktu dan jumlah yang telah ditentukan, maka Pihak Kedua wajib membayar kepada Pihak Pertama denda sebesar 4\% (empat persen) per bulan yang dihitung dari jumlah angsuran maupun kewajiban pembayaran lainnya yang terlambat atau kurang pembayarannya.”

b) Pasal 4 Ayat (4):

"Jika Pihak Kedua lalai atau tidak membayar angsuran, denda, biaya-biaya dan/atau kewajiban pembayaran lain selama 30 (tiga puluh) hari kalender terhitung sejak tanggal jatuh tempo pembayaran, maka dengan lewatnya waktu saja telah memberikan bukti yang cukup bahwa Pihak Kedua telah melalaikan kewajibannya kepada Pihak Pertama berdasarkan Perjanjian ini, sehingga tidak diperlukan lagi peringatan atau somasi apapun dan tanpa diperlukan putusan dari pengadilan, dan Pihak Pertama berdasarkan kelalaian Pihak Kedua tersebut berhak membatalkan Perjanjian ini secara sepihak serta berlaku sanksi pembatalan, sebagaimana diatur dalam Pasal 14 Ayat (2) Perjanjian ini.”

c) Pasal 14 Ayat (1):

"Perjanjian ini tidak dapat dibatalkan secara sepihak, kecuali pembatalan perjanjian oleh Pihak Pertama karena terjadi kelalaian sebagaimana diatur dalam Pasal 4 Ayat (4) atau Pasal 4 Ayat (5) atau Pasal 4 Ayat (6) Perjanjian ini. Mengenai pembatalan perjanjian ini oleh Pihak Pertama dengan cara tersebut, kedua belah pihak telah setuju untuk melepaskan (mengesampingkan) ketentuan yang tercantum dalam Pasal 1266 dan Pasal 1267 Kitab UndangUndang Hukum Perdata.”

d) Pasal 14 Ayat (2):

"Dalam hal terjadi pembatalan Perjanjian ini oleh Pihak Pertama berdasarkan ketentuan Pasal 4 Ayat (4) atau Pasal 4 Ayat (5) atau Pasal 4 Ayat (6) Perjanjian ini, maka Pihak Pertama hanya akan mengembalikan 50\% (lima puluh persen) dari jumlah uang yang telah dibayarkan oleh Pihak Kedua kepada Pihak Pertama setelah 
Volume 2 Nomor 2, Desember 2019

E-ISSN : 2655-7347

dikurangi Booking Fee, Pajak Pertambahan Nilai (PPN), Pajak Penghasilan (PPh) Pihak Pertama, biaya administrasi pembatalan dan kewajiban pembayaran lainnya (apabila ada)”

Pada tanggal 19 Juli 2018 Majelis BPSK memutuskan:

1. Menerima pengaduan Konsumen sebahagian;

2. Mewajibkan Pelaku Usaha Untuk memberikan hak Konsumen mendapatkan informasi yang benar jelas dan jujur;

3. Menyatakan konsumen melanjutkan pembayaran angsuran unit pesanan Tower Lexington Lantai 9 Blok DM seluar 92,22 m2 atas nama Sari Alamsyah;

4. Menolak permohonan Konsumen selebihnya;

5. Membebankan biaya perkara kepada Negara.

Pelaku usaha keberatan terhadap putusan BPSK, sehingga pelaku usaha melakukan upaya keberatan ke pengadilan negeri.

Berdasarkan putusan BSPK pada tanggal 19 juli 2018, PT. Sinar Menara Deli selaku pengusaha merasa keberatan dan mengajukan keberatan atas putusan BPSK tersebut ke Pengadilan Negeri, Sari Alamsyah selaku Konsumen telah cidera janji (wanprestasi) kepada PT. Sinar Menara Deli selaku Pelaku Usaha dan PT. Sinar Menara Deli telah menyampaikan somasi sebanyak 3 (tiga) kali secara tertulis, Selanjutnya telah disepakati pula dalam Pasal 14 ayat 1 Perjanjian Pengikatan Jual Beli Satuan Rumah Susun di Podomoro City Deli-Medan No. 00001109 tanggal 22 April 2015 sebagai berikut :

"Perjanjian ini tidak dapat dibatalkan secara sepihak, kecuali pembatalan perjanjian oleh Pihak Pertama karena terjadi kelalaian sebagaimana diatur dalam Pasal 4 Ayat (4) atau Pasal 4 Ayat (5) atau Pasal 4 Ayat (6) Perjanjian ini. Mengenai pembatalan perjanjian oleh Pihak Pertama dengan cara tersebut, kedua belah pihak telah setuju untuk melepaskan (mengesampingkan) ketentuan yang tercantum dalam Pasal 1266 dan Pasal 1267 Kitab Undang-Undang Hukum Perdata.”

Berdasarkan alasan-alasan tersebut, maka hubungan hukum berdasarkan perikatan/perjanjian antara kedua belah pihak (Konsumen dan 
Volume 2 Nomor 2, Desember 2019

E-ISSN : 2655-7347

Pelaku Usaha) telah berakhir karena pembatalan berdasarkan alasan kelalaian (wanprestasi) dari Konsumen yang telah melampaui batas waktu yang ditetapkan dan bahkan masih diberikan somasi sebanyak 3 (tiga) kali oleh Pelaku Usaha sebagai pihak yang beritikad baik (te geode trouw), Bahwa berakhirnya hubungan hukum perikatan/perjanjian antara kedua belah pihak (Konsumen dan Pelaku Usaha) telah terjadi pada tanggal 20 Januari 2016, Oleh karenanya, tidak ada hal-hal atau objek-objek permasalahan lain yang dapat dijadikan dasar atau alasan yang bisa disengketakan oleh Konsumen kepada Pelaku Usaha di Badan Penyelesaian Sengketa Konsumen maupun di peradilan lain, Selain itu dalam Pasal 22 Perjanjian Pengikatan Jual Beli Satuan Rumah Susun di Podomoro City Deli-Medan No. 00001109 tanggal 22 April 2015 yang disepakati dan ditandatangani oleh kedua belah pihak (Konsumen dan Pelaku usaha) telah dipilih dan disepakati kompetensi Pengadilan Negeri Medan mengenai isi PPJB dengan segala akibat dan pelaksanaannya. Karenanya kompetensi absolut dari objek pengaduan dengan No. 049 / PEN / 2018 / BPSK. MDN bukan merupakan kewenangan dari Badan Penyelesaian Sengketa Konsumen (BPSK) atau BPSK Medan, tapi kewenangan dari Pengadilan Negeri Medan.

Pasal 22 PPJB No. 00001109 tanggal 22 April 2015:

"Mengenai Perjanjian ini dengan segala akibat dan pelaksanaannya, kedua belah pihak memilih tempat kediaman yang tetap dan seumumnya di Kantor Panitera Pengadilan Negeri Medan.” Karena telah berakhirnya hubungan hukum perikatan/perjanjian antara kedua belah pihak sejak tanggal 20 Januari 2016 dan adanya pilihan hakim/sengketa (choice of jurisdiction) di Pengadilan Negeri Medan, maka BPSK Medan tidak berwenang dan tidak beralasan untuk bisa memeriksa dan memutuskan pengaduan Konsumen sebagaimana dalam perkara No. 049/PEN/2018/BPSK.MDN di BPSK Medan.

Sejak awal tahap pra-sidang PT. Sinar Menara Deli selaku Pelaku Usaha telah secara tegas dan tertulis serta berulang kali telah menyampaikan penolakan atas objek pengaduan dari Sari Alamsyah selaku Konsumen 
Volume 2 Nomor 2, Desember 2019

E-ISSN : 2655-7347

diperiksa, ditangani dan diselesaikan di BPSK Kota Medan. Dalam ketentuan Pasal 45 Ayat (2) Undang-Undang Republik Indonesia No. 8 tahun 1999 tentang Perlindungan Konsumen (“UU Perlindungan Konsumen”) telah ditetapkan sebagai berikut :

"Penyelesaian sengketa konsumen dapat ditempuh melalui pengadilan atau di luar pengadilan berdasarkan pilihan sukarela para pihak yang bersengketa.” Oleh karenanya, penyelesaian sengketa konsumen melalui BPSK Kota Medan harus didasarkan pada kehendak sukarela bersama-sama para pihak atau kedua belah pihak, dalam hal ini Pelaku Usaha dan Konsumen, Jadi, bukan atas kehendak satu pihak saja (Sari Alamsyah selaku Konsumen).

Dalam Pasal 4 Ayat (1) Keputusan Menteri Perindustrian dan Perdagangan Republik Indonesia No. 350/MPP/Kep/2001 tentang Pelaksanaan Tugas dan Wewenang Badan Penyelesaian Sengketa Konsumen juga ditetapkan sebagai berikut:

"Penyelesaian sengketa Konsumen oleh BPSK melalui cara Konsiliasi atau Mediasi atau Arbitrase sebagaimana dimaksud dalam Pasal 3 huruf a, dilakukan atas dasar pilihan dan persetujuan para pihak yang bersangkutan”

Tudingan Sari Alamsyah tentang adanya klausula baku yang dilarang adalah tidak benar dan tidak berdasar, Sari Alamsyah telah mengkaitkan isi dari syarat-syarat dan ketentuan-ketentuan dalam Surat Pemesanan Podomoro City Deli-Medan No. 0000001219 tanggal 14 Nopember 2014 dengan ketentuan larangan klausula baku dalam Pasal 18 Ayat (1) dan ayat (2) UndangUndang No. 8 tahun 1999 tentang Perlindungan Konsumen.

PT. Sinar Menara Deli menolak tudingan Sari Alamsyah tersebut karena perjanjian-perjanjian antara PT. Sinar Menara Deli dan Sari Alamsyah telah disetujui, disepakati, dan ditandatangani oleh kedua belah pihak tanpa adanya tekanan atau paksaan apapun, bukan ketentuan yang diberlakukan secara sepihak oleh PT. Sinar Menara Deli sebagaimana satu dan lain.

Dalam Surat Konfirmasi Unit Pesanan No. 002044 tanggal 14 November 2014 dan Surat Pemesanan Podomoro City Deli-Medan No. 0000001219 tanggal 14 Nopember 2014 tercantum secara jelas dan tegas bahwa Pihak 
Volume 2 Nomor 2, Desember 2019

E-ISSN : 2655-7347

Kedua menyatakan telah membaca, mengerti, dan menyetujui setiap dan seluruh syarat-syarat dan ketentuan-ketentuan, sebelum masing-masing pihak menandatangani perjanjian-perjanjian tersebut.

Berdasarkan hal tersebut, Majelis hakim memberikan pertimbangan hukum sebagai berikut: Permohonan keberatan didaftarkan oleh PT. Sinar Menara Deli pada tanggal 4 September 2018 dalam tenggang waktu 14 (empat belas hari) kerja sejak PT. Sinar Menara Deli menerima pemberitahuan putusan Badan Penyelesaian Sengketa Konsumen yaitu pada tanggal 16 Agustus 2018, oleh karenanya secara formal permohonan keberatan tersebut dapat diterima. Antara PT. Sinar Menara Deli dan Sari Alamsyah didalam Perjanjian Perikatan Jual Beli Satuan Rumah Susun di Podomoro City Deli Medan No. 00001109 tanggal 22 April 2015 telah memilih domisili hukum apabila terjadi permasalahan hukum antara PT. Sinar Menara Deli dan Sari Alamsyah pada Pasal 22 menyatakan "Mengenai Perjanjian ini dengan segala akibat dan pelaksanaannya, kedua belah pihak memilih tempat kediaman yang tetap dan seumumnya di Kantor Panitera Pengadilan Negeri Medan.”

Terhadap permasalahan antara PT. Sinar Menara Deli dan Sari Alamsyah adalah mengenai masalah wanprestasi atas perjanjian Jual Beli Satuan Rumah Susun di Podomoro City Deli Medan No. 00001109 tanggal 22 April 2015, maka Majelis berpendapat BPSK Medan tidak berwenang untuk memeriksa sengketa antara PT. Sinar Menara Deli dengan Sari Alamsyah tetapi hal tersebut adalah merupakan kewenangan dari Pengadilan Negeri Medan untuk memeriksa dan memutus perkara aquo.

Setelah Majelis Hakim mempelajari keberatan dari PT. Sinar Menara Deli dan jawaban Sari Alamsyah bahwa hubungan hukum yang timbul antara PT. Sinar Menara Deli dan Sari Alamsyah didasari oleh Perjanjian Jual Beli Satuan Rumah Susun di Podomoro City Deli Medan No. 00001109 tanggal 22 April 2015.

Berdasarkan pertimbangan-pertimbangan hukum tersebut Majelis Hakim menyimpulkan Majelis Badan Penyelesaian Sengketa Konsumen telah 
Volume 2 Nomor 2, Desember 2019

E-ISSN : 2655-7347

keliru dalam memeriksa dan memutus perkara aquo sehingga Putusan dari Badan Penyelesaian Sengketa Konsumen (BPSK) Medan No. 049/PEN/2018/ BPSK.MDN tanggal 19 Juli 2018 haruslah dinyatakan Batal Demi Hukum.

Menurut Joko Kundaryo, S.H., M.M dalam acara yang diselenggarakan oleh BPSK DKI Jakarta pada tanggal 24 Oktober 2019 di aula serba guna dinas koperasi usaha kecil dan menengah serta perdagangan provinsi DKI Jakarta mengenai "Penerapan Dan Akibat Hukum Pecantuman Klausula Baku Dalam Dokumen dan/atau Perjanjian” beliau sebagai moderator dan mewakili anggota BPSK dalam acara tersebut, beliau mengatakan bahwa apabila para konsumen mendapatkan barang atau jasa yang tidak sesuai atau prilaku pelaku usaha yang merugikan konsumen, segera laporkan hal tersebut kepada BPSK, maka pelaku usaha tersebut dapat langsung di panggil, apabila pelaku usaha tidak dating ketika dipanggil, maka akan dipanggil untuk kedua kalinya, apabila tidak dating maka BPSK dapat meminta polisi setempat untuk menjemput paksa pelaku usaha tersebut, dan apabila salah satu pihak melaporkan sengketa tersebut ke BPSK maka sengketa tersebut sudah dapat ditindak lanjuti.

Menurut bu sularsi selaku wakil ketua BPSK Provinsi DKI Jakarta dan pengurus harian YLKI. Badan Penyelesaian Sengketa Konsumen di Indonesia mengacu pada Small Claim Court Malaysia. Di Malaysia small claim court di batasi hanya Rp. 100.000.000,- (seratus juta rupiah). Di Indonesia untuk batasan tersebut belum ada, dalam praktiknya masih banyak sengketa perumahan yang nilainya satu unit rumah dapat mencapai Rp. 2.000.000.000,- (dua milyar rupiah) dan ditangani oleh BPSK. BPSK di Indonesia bertujuan untuk mendekatkan konsumen dengan BPSK, terutama untuk konsumen yang minim pengetahuan, untuk konsumen yang enggan untuk mengadukan kerugiannya, untuk konsumen yang mempunyai masalah ekonomi, karena untuk mengajukan gugatan ke pengadilan negeri membutuhkan biaya yang cukup besar dan membutuhkan waktu yang lama dalam penyelesaiannya. BPSK berada pada daerah tingkat 2, dengan adanya otonomi daerah, sarana dan prasarana, honor, bangunan BPSK pun 
Volume 2 Nomor 2, Desember 2019

E-ISSN : 2655-7347

tergantung dari gubernur daerah tersebut. Untuk BPSK di DKI Jakarta masih lebih baik dari pada BPSK di daerah-daerah lain meskipun untuk bangunan masih meminjam, Namun gubernur di DKI Jakarta sudah memperhatikan hal tersebut.

Dalam mengajukan laporan kepada BPSK harus sudah ada sengketa, dalam artian konsumen harus terlebih dahulu menghubungi pihak pelaku usaha dan mengutarakan kerugiannya atau ketidakpuasannya. Sengketa baru terjadi apabila jawaban pelaku usaha tidak memuaskan pihak konsumen atau pelaku usaha tidak memberikan jawaban terhadap komplain yang disampaikan oleh konsumen. Dalam mengajukan laporan kepada BPSK tidak boleh menggunakan pihak ke-3 atau lawyer, karena apabila menggunakan lawyer akan bertentangan dengan prinsip BPSK yaitu cepat, murah dan sederhana. Menurut beliau apabila menggunakan lawyer tentunya lawyer pada umumnya akan mengulur waktu dengan tujuan honor yang akan diterima akan lebih besar. Namun pada kenyataannya ada beberapa yang mengajukan laporan kepada BPSK menggunakan lawyer. Beliau juga menjelaskan perbedaan konsiliasi dengan mediasi, dalam penyelesaian konsiliasi BPSK akan menjadi pihak ke-3 yang bersifat pasif pihak konsumen dan pelaku usaha yang berunding, apabila melalui mediasi, mediator juga sebagai pihak ke-3 yang sifatnya aktif untuk mendamaikan para pihak mecari jalan tengah untuk mencapai win-win solution, apabila melalui arbitrase BPSK akan membetuk majelis yang terdiri dari 3 orang mewakili unsur pemerintah, pelaku usaha dan konsumen, dalam hasil akhirnya arbitrase winlose, oleh karena itu dari pihak BPSK akan menawarkan cara mediasi terlebih dahulu.

Dalam mengajukan laporan kepada BPSK tidak mengenal tuntutan imateril, hanya materil saja, apabila ingin mengajukan imateril harus diajukan ke pengadilan negeri. Mengenai prosedur pelaporan sengketa konsumen ke BPSK dimulai dari konsumen mengajukan laporan kepada BPSK, lalu BPSK akan membuat surat panggilan kepada pelaku usaha, apabila pelaku usaha tidak hadir maka BPSK dapat meminta kepolisian setempat untuk melakukan 
Volume 2 Nomor 2, Desember 2019

E-ISSN : 2655-7347

upaya paksa untuk menjemput pelaku usaha, apabila pelaku usaha hadir maka BPSK akan menanyakan apakah dari pihak konsumen dan pelaku usaha sama-sama sepakat sengketa tersebut diselesaikan melalui BPSK, apabila sepakat selanjutnya BPSK akan menanyakan cara penyelesaian mana yang disepakati para pihak apakah mediasi, konsiliasi atau arbitrase. Apabila salah satu pihak tidak setuju dari salah satu pertanyaan yang di ajukan oleh BPSK tersebut, maka BPSK tidak berwenang untuk menangani sengketa tersebut.

Dalam Mediasi kita akan melihat kedepan sengketa tersebut sudah terjadi kedepannya mau seperti apa, dan mencari win-win solution, sedangkan arbitrase melihat kebelakang, dokumen-dokumen akan diperiksa dan kejadian yang menyebabkan sengketa. Sampai sekarang konsumen masih minim kesadaran dan pengatahuan tentang konsumen, lalu beliau juga mengatakan bahwa seharusnya pelaku usaha memberikan reward kepada konsumen yang memberikan kritik terhadap produk / jasa yang diberikan oleh pelaku usaha, karena menurut beliau dari sekian banyak konsumen hanya konsumen tersebut yang berani untuk memberikan kritik, dan seharusnya pelaku usaha menganggap konsumen sebagai evaluator, apabila sudah ada yang mengajukan komplain, maka pelaku usaha dapat melakukan antisipasi untuk menarik produk/ jasa yang diedarkan tersebut, agar tidak ada lagi konsumen lain yang menuntut. Beliau juga mengatakan BPSK hanya untuk sengketa individu, untuk sengketa yang banyak pihaknya tidak dapat diselesaikan di BPSK harus melalui Pengadilan Negeri. Lalu seharusnya laporan yang diajukan kepada BPSK harus konsumen langsung yang membuat laporan tidak diperbolehkan menggunakan pihak ke-3/ lawyer, dan konsumen yang membuat laporan haruslah konsumen akhir.

Terkait dengan kasus ini menurut bu Sularsi untuk melakukan laporan kepada BPSK ada beberapa syarat yang harus terpenuhi, yaitu harus adanya sengketa terlebih dahulu. Sengketa yang dimaksud yaitu konsumen harus terlebih dahulu melakukan laporan atau melakukan aduan kepada pelaku usaha tentang kerugiannya atau ketidakpuasannya. Dalam kasus ini Sari Alamsyah sudah melakukan laporan tersebut, Sari Alamsyah sudah 
Volume 2 Nomor 2, Desember 2019

E-ISSN : 2655-7347

mengirimkan surat kepada PT. Sinar Menara Deli yang pada pokoknya Sari Alamsyah meminta agar perjanjian tersebut tidak dibatalkan karena Sari Alamsyah sedang mengalami masalah keuangan dan berjanji akan segera melunasi tunggakan pembayaran tersebut. PT. Sinar Menara Deli menerima keluhan tersebut dan telah setuju untuk Sari Alamsyah melanjutkan pembayaran tersebut, namun Sari Alamsyah tidak melakukan pembayaran apapun setelah permohonan tersebut. Sehingga dalam sengketa antara PT. Sinar Menara Deli dengan Sari Alamsyah tidak ada sengketa dan seharusnya Badan Penyelesaian Sengketa Konsumen Medan menolak menangani sengketa ini, karena syarat pertama tentang adanya sengketa tidak terpenuhi. Setelah sengketa, syarat berikutnya setelah pelaku usaha di panggil oleh BPSK, anggota BPSK akan menanyakan apakah pelaku usaha setuju sengketa tersebut di tangani atau diselesaikan melalui BPSK, apabila pelaku usaha tidak setuju maka BPSK harus menolak menangani sengketa tersebut.

Sengketa antara PT. Sinar Menara Deli dengan Sari Alamsyah tidak memenuhi syarat tersebut, PT. Sinar Menara Deli sudah menyampaikan secara lisan maupun melalui surat kepada BPSK Medan bahwa PT. Sinar Menara Deli keberatan dan menolak apabila sengketa tersebut diselesaikan melalui BPSK, namun BPSK tetap melanjutkan menangani sengketa tersebut sampai pada akhirnya mengeluarkan putusan yang pada pokoknya Sari Alamsyah dapat melanjutkan angsuran 1 unit rumah susun (apartemen) tersebut setelah kurang lebih 2 tahun 3 bulan setelah pembatalan perjanjian.

Syarat selanjutnya apabila para pihak setuju untuk diselesaikan melalui BPSK maka anggota BPSK akan menanyakan kembali dengan cara seperti apa sengketa akan diselesaikan, melalui mediasi, konsiliasi atau arbitrase. Apabila konsumen dan pelaku usaha setuju dengan satu cara maka BPSK dapat melanjutkan menangani sengketa tersebut, namun apabila tidak ditemuinya kesepakatan dengan cara apa yang akan digunakan maka BPSK harus menolak menangani sengketa tersebut, karena BPSK tidak berwenang menangani sengketa tersebut. Menurut Dr. Ermanto Fahamsyah, S.H.,M.H mengenai sengketa ini beliau mengatakan sengketa antara PT. Sinar Menara 
Volume 2 Nomor 2, Desember 2019

E-ISSN : 2655-7347

Deli dengan Sari Alamsyah merupakan salah satu bukti ketika aturanaturannya sudah jelas namun anggota BPSK masih banyak yang belum memahami aturan-aturan tersebut, meskipun tidak seluruh BPSK demikian. Maka seharusnya BPSK kota Medan menolak menangani sengketa antara PT. Sinar Menara Deli dengan Sari Alamsyah.

Dalam sengketa antara PT. Sinar Menara Deli dengan Sari Alamsyah BPSK juga tidak memahami sengketa tersebut secara menyeluruh. Dalam sengketa ini yang di laporkan oleh Sari Alamsyah selaku Konsumen adalah mengenai klausla baku yang terdapat pada Butir 6 Surat Pemesanan Podomoro City Deli-Medan No. 0000001219 tanggal 14 Nopember 2014 berbunyi sebagai berikut:

"Apabila terjadi keterlambatan pembayaran selama 30 (tiga puluh) hari kalender terhitung sejak tanggal jatuh tempo kewajiban pembayaran yang bersangkutan, maka Penerima Pesanan berhak membatalkan secara sepihak pemesanan atas Unit Pesanan, dengan melepaskan ketentuan dalam Pasal 1266 dan Pasal 1267 Kitab Undang-Undang Hukum Perdata ...”

Sari Alamsyah tidak mendapatkan penjelasan mengenai “melepaskan ketentuan dalam Pasal 1266 dan Pasal 1267 Kita Undang-Undang Hukum Perdata” sehingga Sari Alamsyah mengadukan hal tersebut kepada BPSK medan. Sedangkan mengenai "melepaskan ketentuan dalam Pasal 1266 dan Pasal 1267 Kita Undang-Undang Hukum Perdata” hal tersebut tidak termasuk klausula baku yang dilarang dalam UUPK. Meskipun sudah diatur dalam UUPK menurut Dr. David ML Tobing, S.H., M.Kn dalam acara yang diselenggarakan oleh BPSK DKI Jakarta pada tanggal 24 Oktober 2019 di aula serba guna dinas koperasi usaha kecil dan menengah serta perdagangan provinsi DKI Jakarta mengenai "Penerapan Dan Akibat Hukum Pecantuman Klausula Baku Dalam Dokumen dan/atau Perjanjian” tidak selalu klausula baku dapat diterapkan sesuai dengan aturan yang sudah diatur oleh UUPK terkadang aturan tersebut dapat dikesampingkan, seperti contoh apabila konsumen membeli pakaian dalam, tentu tidak mungkin pelaku usaha menerima kembali pakaian dalam yang sudah dicoba atau dibawa pulang oleh konsumen. 
Volume 2 Nomor 2, Desember 2019

E-ISSN : 2655-7347

Mengenai memberikan penjelasan yang diwajibkan Undang-Undang Perlindungan Konsumen terdapat dalam beberapa pasal, berdasarkan Pasal 7 Huruf b Undang-Undang Nomor 8 Tahun 1999 tentang Perlindungan Konsumen terkait kewajiban pelaku usaha, sebagai berikut:

"Memberikan informasi yang benar, jelas dan jujur mengenai kondisi dan jaminan barang dan/atau jasa serta memberi penjelasan penggunaan, perbaikan dan pemerliharaan”

Sehingga mengenai Butir 6 Surat Pemesanan Podomoro City Deli-Medan No. 0000001219 tanggal 14 Nopember 2014 tersebut diluar kewajiban pelaku usaha untuk memberikan penjelasan dan penjelasan mengenai butir-butir yang ada dalam perjanjian tidak termasuk hal yang wajib dilakukan oleh pelaku usaha dalam kasus ini PT. Sinar Menara Deli tidak wajib menjelaskan Butir 6 Surat Pemesanan Podomoro City Deli-Medan No. 0000001219 tersebut. Sehingga seharusnya klausula baku PT. Sinar Menara Deli sudah sesuai dengan aturan yang ada.

Selain tidak cermat dalam hal klausula baku, BPSK kota medan juga tidak memahami sengketa ini secara keseluruhan, karena pada dasarnya sengketa ini ada karena Sari Alamsyah sudah tidak dapat lagi melanjutkan cicilan Rumah susun (apartemen) yang dibeli oleh Sari dengan cara angsuran dan berdasarkan perjanjian dengan PT. Sinar Menara Deli apabila konsumen lalai tidak membayar cicilan lewat 30 hari maka perjanjian tersebut dapat dibatalkan sepihak oleh pihak PT. Sinar Menara Deli dan untuk menutupi hal tersebut Sari Alamsyah selaku konsumen melaporkan PT. Sinar Menara Deli ke BPSK dengan alasan klausula baku.

Dalam sengketa antara PT. Sinar Menara Deli dengan Sari Alamsyah, Konsumen tidak memiliki itikad baik. Berdasarkan hasil wawancara dengan ibu Sularsi, beliau mengatakan untuk mengajukan aduan kepada BPSK harus sudah ada sengketa antara pelaku usaha dengan konsumen, dalam artian konsumen harus menghubungi pelaku usaha terlebih dahulu untuk menyampaikan keluhannya atau kerugiannya dalam menggunakan barang atau jasa yang diberikan oleh pelaku usaha, apabila pelaku usaha tidak menjawab atau jawabannya tidak memuaskan baru dapat disebut sebagai 
Volume 2 Nomor 2, Desember 2019

E-ISSN : 2655-7347

sengketa dan BPSK baru berwenang menangani sengketa tersebut apabila kedua pihak setuju untuk diselesaikan oleh BPSK dan menyetujui cara yang akan dilakukan apakah melalui mediasi, konsiliasi atau arbitrase dan apabila salah satu pihak tidak setuju dengan salah satu pilihan tersebut maka BPSK tidak berwenang untuk menangani sengketa tersebut.

Dalam kasus ini Sari Alamsyah sudah menghubungi PT. Sinar Menara Deli via surat yang pada pokoknya sari meminta agar perjanjian tersebut tidak dibatalkan karena, Sari Alamsyah sedang mengalami masalah ekonomi dan berjanji akan melunasinya via KPA Bank BNI segera. Lalu PT. Sinar Menara Deli selaku pelaku usaha sudah setuju dengan permohonannya tersebut, namun Sari Alamsyah tidak melakukan pembayaran sedikitpun setelah mengirim surat tersebut, sampai pada akhirnya setelah kurang lebih 2 tahun 3 bulan Sari Alamsyah mengajukan aduan kepada BPSK dan seharusnya BPSK kota medan menyatakan tidak berwenang untuk menangani sengketa tersebut. Jika disimpulkan pada praktiknya ada 3 syarat agar BPSK berwenang menangani sengketa yaitu sudah ada sengketa antara pelaku usaha dengan konsumen, para pihak setuju sengketa tersebut diselesaikan melalui BPSK, para pihak setuju dan sepakat dengan satu cara untuk menyelesaikan sengketa tersebut. Apabila salah satu syarat tersebut tidak terpenuhi, maka BPSK tidak berwenang menangani sengketa tersebut.

Menurut Dr. Ermanto Fahamsyah, S.H., M.H badan Penyelesaian Sengketa Konsumen memang mempunyai masalah karena aturan beracara melalui BPSK tidak diatur secara khusus seperti Peraturan Mahkamah Agung Nomor 1 Tahun 2006 tentang tata cara pengajuan keberatan terhadap putusan Badan Penyelesaian Sengketa Konsumen, dalam Undang-Undang Nomor 8 Tahun 1999 tentang Perlindungan Konsumen pun tidak detail mengenai beracara melalui BPSK tersebut. Selain aturan tersebut, BPSK mempunyai masalah lain, antara lain:

a) Putusan BPSK seringkali tidak berkualitas;

b) Aturan mengenai beracara melalui BPSK belum clear;

c) Majelis BPSK belum memahami aturan-aturan yang ada. 
Volume 2 Nomor 2, Desember 2019

E-ISSN : 2655-7347

Masalah dalam BPSK biasanya timbul karena belum ada aturannya dalam artian aturannya belum jelas yang menyebabkan terjadinya masalah, namun ada juga yang aturan-aturannya sudah jelas namun anggota BPSK sendiri belum memahami aturan-aturan yang ada tersebut, sehingga terjadilah masalah. Lalu beliau juga menjelaskan bahwa BPSK tersebut berada di daerah tingkat 2, sehingga untuk oprasional BPSK tersebut tergantung dari kepala daerah di daerah tersebut. Salah satu kendala dalam BPSK juga terkait honor, tempat oprasional, perekrutan anggota BPSK dan lainnya sehingga hal tersebut dapat saja mempengaruhi kualitas dari anggota BPSK itu sendiri, karena masih kurangnya perhatian dari kepala daerah terhadap BPSK seringkali dalam merekrut anggota seadanya yang pada akhirnya mempengaruhi kualitas dari anggota BPSK tersebut, namun tidak semua BPSK demikian. Jika dikaitkan dengan teori yang dikemukakan oleh friedmann legal substance, legal structure dan legal culture, secara subtansi beracara di BPSK aturannya belum clear, jika dilihat dari struktur hukumnya (legal structure) sudah disediakan BPSK yang anggotanya belum semua memahami aturan-aturan yang sudah ada, secara culture atau budayanya tentu dapat terbentuk dari beberapa faktor, salah satunya kurang perhatian dari pemerintah tentang sarana dan prasarana, honor, merekrut anggota dan lainnya akan mempengaruhi kinerja anggota BPSK yang akan menjadi suatu budaya dalam menangani sengketa, namun tidak seluruh BPSK demikian.

Sengketa yang dapat diajukan ke BPSK tentunya pembuktiannya relatif sederhana, BPSK merupakan semi-semi litigasi, meskipun demikian banyak pembuktian yang tidak sederhana juga diselesaikan melalui BPSK. Meskipun tidak semua BPSK demikian, ada juga BPSK yang sudah cukup baik dalam menjalankan tugas dan wewenangnya, tentunya BPSK kedepannya harus didukung oleh pemerintah dan sebaiknya dibuat aturan khususnya seperti PERMA Nomor 1 Tahun 2006 tentang tata cara pengajuan keberatan terhadap putusan Badan Penyelesaian Sengketa Konsumen, dengan dibuat aturan khusus untuk beracara melalui BPSK diharap dapat mendukung BPSK dalam menjalankan tugas dan wewenangnya. 
Volume 2 Nomor 2, Desember 2019

E-ISSN : 2655-7347

Menurut Dr. Ermanto Fahamsyah, S.H., M.H. mengenai sengketa ini beliau mengatakan sengketa antara PT. Sinar Menara Deli dengan Sari Alamsyah merupakan salah satu bukti ketika aturan-aturannya sudah jelas namun anggota BPSK masih banyak yang belum memahami aturan-aturan tersebut, meskipun tidak seluruh BPSK demikian.

\section{PENUTUP}

\section{A. Kesimpulan}

BPSK tidak berwenang menangani sengketa antara PT. Sinar Menara Deli dengan Sari Alamsyah karena tidak memenuhi syarat bahwa harus adanya sengketa antara PT. Sinar Menara Deli dengan Sari Alamsyah dan para pihak harus setuju dan sepakat sengketa tersebut diselesaikan melalui BPSK. Jika dilihat hanya dari segi undang-undang Nomor 8 Tahun 1999 tentang Perlindungan Konsumen BPSK berwenang menangani sengketa tersebut, karena tidak adanya batasan dalam aturan tersebut mengenai sengketa seperti apa yang dapat dan yang tidak dapat diselesaikan oleh BPSK.

\section{B. Saran}

Saran untuk pemerintah agar dibuatkan aturan secara khusus untuk beracara melalui Badan Penyelesaian Sengketa dan dibuat secara detail kewenangan Badan Penyelesaian Sengketa Konsumen ini, untuk sengketa seperti apa yang dapat ditangani oleh BPSK dan yang tidak dapat ditangani oleh BPSK, besaran nominal sengketa yang dapat dijangkau oleh BPSK dan melakukan evaluasi terhadap anggota BPSK, dan khususnya untuk para gubernur agar lebih memperhatikan Badan Penyelesaian Sengketa Konsumen.

\section{DAFTAR PUSTAKA}

\section{A. Buku}

Muhammad, Abdulkadir. Hukum Perdata Indonesia. (Bandung: Citra Aditya Bakti, 1990).

Kansil, C.S.T. dan Chistine S.T. Kansil. Modul Hukum Perdata Termasuk Asas-Asas Hukum Perdata, (Jakarta: Pradnya Paramita, 2000). 
Volume 2 Nomor 2, Desember 2019

E-ISSN : 2655-7347

Kartohadiprodjo, Soediman. Pengantar Tata Hukum di Indonesia. (Jakarta: Ghalia Indonesia, Cet. X. 1984).

Subekti, Hukum Perjanjian, (Jakarta: Intermasa, Cet. XV, 1994).

Subekti, Pokok-pokok Hukum Perdata. (Jakarta: Intermasa, 1985).

Soekanto, Soerjono dan Sri Mamudji, Penelitian Hukum Normatif: Suatu Tinjauan Singkat, (Jakarta: RajaGrafindo Persada, 2006).

\section{B. Artikel Jurnal}

Hadiati, Mia. Mariske Myeke Tampi. “Efektivitas mediasi dalam penyelesaian sengketa konsumen oleh badan penyelesaian sengketa konsumen (BPSK) di D.K.I Jakarta”. Jurnal Hukum Prioris. Vol. 6. No. 1 Tahun 2017. 